\title{
Consumption Pattern of Fish in Uttar Pradesh, India
}

\author{
Ravi Shankar Kumar ${ }^{1 *}$, Praduman Kumar ${ }^{2}$, M. Krishnan ${ }^{3}$, A. Vinay ${ }^{1}$ and \\ Dhande Kranthi Kumar ${ }^{1}$
}
${ }^{1}$ ICAR-Central Institute of Fisheries Education, Mumbai - 400061 Maharashtra, India
${ }^{2}$ Division of Agricultural Economics, Indian Agricultural research Institute (IARI),
N. Delhi 110012, India
${ }^{3}$ Education Systems Management, ICAR-NAARM, Hyderabad-500030, Telangana, India
*Corresponding author

\section{A B S T R A C T}

\begin{tabular}{|l|}
\hline Key w or d s \\
Fish, consumption, \\
Elasticity, \\
Multistage \\
budgeting \\
framework, Uttar \\
Pradesh, India. \\
\hline Article Info \\
\hline Accepted: \\
26 August 2017 \\
Available Online: \\
10 September 2017 \\
\hline
\end{tabular}

The advance production technologies, higher economic growth, population explosion and shifts in dietary pattern create driving force for rapid growth in the demand for food of animal origin. Fish is a very important component of food items of animal origin. The consumption of fish has grown faster than that of any other animal product. Disparities in the fish consumption pattern exist widely across the income groups, location of the households (rural, urban, costal, etc.), and regions. This study has been conducted in Uttar Pradesh, India. As far as this paper is concerned, per capita consumption of fish is very low due to large vegetarian population. The estimated per capita consumption for fish is about $1.1 \mathrm{~kg}$ / annum (2011). "Multistage budgeting framework" was used for the present study on "Fish Consumption in Uttar Pradesh". Income elasticity of demand is estimated for fish in Uttar Pradesh and it is found to be 0.77 in 2011. Price elasticity of demand was found -1.32 , which indicated that demand for fish is elastic implying that demand is the function of price In Uttar Pradesh. The probability of increased share of fish in consumption schedule of non-vegetarian population of states depends on the income, level of education, increased awareness of the contribution of fish in the nutritional profile, improved time, space and form utility of fish in Uttar Pradesh.

\section{Introduction}

Economic growth also brings positive changes in the production, processing, distribution and marketing of food. Income, prices, individual preferences and beliefs, cultural traditions, geographical, environmental, social and economic factors influences the dietary pattern, which evolves over time. Food strategies must not merely be directed at ensuring food security for all, but must also achieve the consumption of adequate quantities of safe and good quality foods that together make up a healthy diet and are play an important role ensuring the food security and nutritional security.

As it is known to all, fish is an important source of protein and have a special place in healthy and nutritious food among nonvegetarian items. Demand for fish is increasing day by day because people are becoming more and more aware of the importance of fish as a source of nutritious 
food. Demand of fish varies from place to place and also across time periods.

A significant growth is found in fish consumption throughout the world with the increase in diversification of food and sifting of people towards nutritious food. In 2013, it is found that fish account about 17 percent of the global population's intake of animal protein and $6.7 \%$ of the total protein consumed. Beside that fish provided almost 20 percent of their average per capita intake of animal protein to the more than 3.1 billion people throughout the world. In addition to being one of the richest source of easily digestible, high quality proteins which contains all essential amino acids it also provides essential fats like- long chain omega-3 fatty acids, vitamins like-D, A and B and minerals like-including calcium, iodine, zinc, iron and selenium. Even small quantities of fish have a significant positive nutritional impact on plant based diets, as far as developing and least-developed countries are concerned.

Fish is rich in unsaturated fats, which provides health benefits in protection against cardiovascular diseases. This unsaturated fat also needed for foetal and infant development of the brain and nervous system. So, due to its valuable nutritional properties, it can also play an important role in correcting unbalanced diets and, through substitution, in countering obesity (FAO 2016).

In 2013, per capita apparent fish consumption in industrialized countries was found to be $26.8 \mathrm{~kg} /$ annum (FAO, 2016), which shows that people is become more aware about importance of fish as a health food.

As far as ESN Nutrition country profile for India is concerned, it has reported that fish and seafood provide only 2 percent of the total dietary energy supply whereas cereals provide 62 percent (FAO, 2005). So there is a need to increase the consumption of fish and seafood in India.

As far as fisheries sector in India is concerned, it is a very important economic activity and also a flourishing sector, which have varied resources and potentials. After the Independence of India, fisheries has kept together with agriculture been recognized as an important sector. The vibrancy of the sector can be visualized by the statistical scenario that, 11-fold increase is achieved in fish production of India in just six decades, (i.e. from 0.75 million tonnes in $1950-51$ to 9.6 million tonnes during 2012-13). Besides meeting the domestic needs, fisheries sector is also associated with the dependence of over 14.5 million people on fisheries activities for their livelihood as well as foreign exchange earnings of the country (the tune of US\$ 3.51 billion, 2012-13), amply justifies the importance of the fisheries sector on the country's economy as well as livelihood security and food security (FAO, 2016).

Per capita consumption of fish in India is 9.8 $\mathrm{kg} /$ annum (FAO, 2011). However Indian Council of Medical Research recommends that the per capita consumption should be 12 $\mathrm{kg} /$ annum (food and beverage news, august 2016)

The present study is focuses about consumption pattern of fish in Uttar Pradesh. Uttar Pradesh is a land locked state having vast water resources in terms of rivers, lakes, reservoirs and ponds. As far as fish consumption is concerned, it is very low in Uttar Pradesh. Per capita consumption of fish was found to be $1.1 \mathrm{~kg}$ / annum in 2011, which was very less in compare to fish consumption of India (9.8 kg in 2011).

\section{The data}

National Sample Survey Organisation (NSSO) is the only source of household fish 
consumption data in India. This NSSO data gives state wise consumption of food and in this study NSSO household consumption data of food specially fish has been taken into account. Six NSSO round of household consumption data of Uttar Pradesh was used to study the consumption pattern of fish in Uttar Pradesh. NSSO data of year 1983, 1987, 1993, 1999, 2004 and 2011 was used for this purpose. For estimation of elasticities NSSO data of 2011 was used.

Uttar Pradesh is the fourth largest state in India as far as area is concerned whereas it is largest states as far as population is concerned. The state is located in the northcentral part of the country. Uttar Pradesh is Situated between $23^{\circ} 52^{\prime} \mathrm{N}$ and $31^{\circ} 28^{\prime} \mathrm{N}$ latitudes and $77^{\circ} 3^{\prime}$ and $84^{\circ} 39^{\prime} \mathrm{E}$ longitudes. The climate of Uttar Pradesh can also vary widely, with temperatures as high as $47^{\circ} \mathrm{C}$ in summer, and as low as $-1{ }^{\circ} \mathrm{C}$ in winter.

\section{Demand model}

Multistage budgeting framework (MBF) is the best approach to study the fish consumption behaviour of the target location and for modelling the same, in which concept of expenditure system at different level or stages is used (Deaton and Muellbauer (1980), Blundell et al., (1993) and Heien and Wessells (1990). Kumar (2005) estimated demand for fish in India using the same MBF. The same approach also used by Dey (2000) and Garcia et al., (2005) for studying fish demand in Bangladesh and Philippines respectively. The QUAIDS model which is nothing but a quadratic extension of the Deaton and Muellbauer's linear approximate AIDS model (1980), suggested by Banks et al., (1997)was used for this study.

Consumption expenditure on food and nonfood commodity was affected not only by income and pricebut by some demographic characteristics of household.
The model contains 3 stages.

\section{Stage 1: Food Expenditure Function}

$\mathrm{FD}=\mathrm{f}\left(\mathrm{PF}, \mathrm{PNF}, Y, Y^{2}, Z\right) \ldots(1)$

$\mathrm{PF}=$ Geometric mean of food prices $=\Sigma \mathrm{Wj} \ln$ $\mathrm{Pj}$

$\mathrm{Wj}=$ share of $\mathrm{jth}$ commodity in food expenditure

$\mathrm{P}=$ price of $\mathrm{j}^{\text {th }}$ commodity

$\mathrm{PNF}=$ price index for non-food commodity

$\mathrm{Y}=$ Income variable capturing linear expenditure

$Y^{2}=$ Income variable capturing non-linear expenditure

$\mathrm{Z}=\mathrm{A}$ dummy variable representing demographic factor which may affecting consumption like family size, urban, rural etc.

Equation 1 assumes negligible substitution effect between food and non-food.

Income effect of changes in price index for non-food commodity is also taken into consideration by this proxy variable and substitution effect between food and non-food commodities is supposed to be negligible.

The variable $\mathrm{Y}$ indicated the income which capturing both linear and squared forms while $Y^{2}$ (a quadratic term) captured non-linear food consumption behavior of households.

\section{Stage 2}

In stage 2, MFE expenditure (FS) was specified. MFE expenditure is the function of substitute and complimentary foods. It was defined as follows: 
$\mathrm{FS}=\mathrm{f}\left(P, \mathrm{FD}^{*}, \mathrm{FD}^{*^{2}}, Z\right)$

$\mathrm{P}=$ vector of prices of various food commodities

$\mathrm{FD}=$ Instrumental variable calculated in stage 1.

$\mathrm{FD}^{2=}$ Indicates the non-linear forms of FD.

$\mathrm{MFE}=$ Meat, Fish and Egg.

Here, in $1^{\text {st }}$ stage food expenditure, in $2^{\text {nd }}$ stage MFE expenditure and in $3^{\text {rd }}$ stage fish expenditure is taken.

\section{Stage 3}

In stage 3, QUAIDS model is specified for fish. Budget share of fish $\left(\mathrm{W}_{\mathrm{i}}\right)$ was the function of MFE prices and MFE expenditure. QUAIDS model is given by following system of equation:

$W_{i}=\mathrm{f}\left(\mathrm{PF}, \mathrm{FS}^{*} / P^{*}, \mathrm{FS}^{*} / P^{*}, Z, \mathrm{IMR}_{i}\right) \ldots$

$\mathrm{P}^{*}=$ Household-specific stone's price index for fish $\left(\log P^{*}=\Sigma_{k} W_{k} \log P_{k}\right)$. This stone price was used in the model for estimation of non-linear form of the AIDS model in linear form. Although some economists like Moschini (1995), Asche and Wessels (1997) criticize and felled that price index may lead to introduction of measurement errors; in spite of the fact stone price is used.

The separability of fish was assumed to be low in QUAIDS model. For multistage framework, separability assumption was necessary. It required that the marginal utilities derived from the fish consumption should be independent of marginal utilities derived from other food commodities (Eales and Unnevehr 1988, Jorgenson et al., 1988, Yen and Roe 1989, Michalek and Keyzer 1992).
For the correction of possible bias due to presence of zero consumption for specific fish type, Inverse Mill ratios (IMRs) are used (Heckman 1979, Cheng and Capps 1988, Heien and Wessells 1990, Byrne et al., 1996). Abstension or corner solution in the household's utility maximization problem is responsible for zero consumption (Shonkwiler and Yen 1999, Perali and Chavas 2000). When consumers are unable to pay the price of certain high value fish then it is called corner solution and abstention arises due to non-preferences or infrequent purchases of certain fishes. In both the cases value of Wiis zero. Tobit specification in stage 2 may also be used for this purpose.

Uncompensated price elasticities for specific types of fishes are estimated by using outcome of QUAIDS model as follows:

$\xi_{i j}=\left(b_{i j} / W_{i}\right)-\left\{c_{1 i}+2 c_{2 i} \ln (\mathrm{FS})\right\}\left(W_{j} / W_{i}\right)-k_{i j}$

Where,

$\mathrm{K}_{\mathrm{ij}}=$ Knonecker delta $\left(\mathrm{K}_{\mathrm{ij}}=1\right.$ for own price elasticity and it is zero for cross-price elasticity.

$\mathrm{W}_{\mathrm{i}}=$ consumption share of $i^{\text {th }}$ fish and $\mathrm{b}_{\mathrm{i}}$ and $c_{i}$ are the parameter estimates of QUAIDS model.

Fish expenditure elasticity is given by following equation:

$$
\eta_{i}=\left(c_{1 i}+2 c_{2 i} \ln (\mathrm{FS}) / W_{i}\right)+1
$$

Where $n_{i}=$ Fish expenditure elasticity.

The income elasticity $\eta_{i}^{Y}$ for fish is computed with the help of food expenditure elasticity $\eta^{\mathrm{FD}}$ and MFE expenditure elasticity $\eta^{\mathrm{FS}}$ from stage 1 and stage 2 respectively by using following equation: 
$\eta_{i}^{Y}=\left(\eta^{F D}\right)\left(\eta^{F S}\right)\left(\eta_{i}\right)$

The price and income elasticities of different fish for the different levels of income were computed by substituting the specific income level of different group in elasticity formula. Only one set of demand parameters was needed to be estimated from elasticity estimates of different income groups by using this technique (Park et al., 1996).

\section{Results and Discussion}

In general, with the increase in income, people shifted from food expenditure to nonfood expenditure and Uttar Pradesh is not exception to that. So, it was observed that proportion food expenditure decreased while non-food expenditure increased with increase in income over years in Uttar Pradesh. But it is relatively less because of large scale of poverty in state. Fig-2, showed the pattern of food and non-food expenditure in Uttar Pradesh from year 1983 to 2011. It was found that expenditure for both food and non-food items increased over the period of time but the increase was slightly more for non-food items than food items (Kumar, 2016).

Share of fish expenditure in MFE (Meat, Fish and Egg) expenditure was low, which indicates the low consumption of fish in Uttar Pradesh as shown in Fig-3.
Table 1 showed the consumption pattern of fish in Uttar Pradesh. It is found that consumption of fish was very less in Uttar Pradesh (1.10 kg/capita/annum). The cause for low consumption may be due to large vegetarian population $(50 \%)$ and also because of the fact that fish was a low priority item in the food basket of even non vegetarian population.

\section{Income elasticity}

Income elasticity is estimated by using the outcome of three stage budgeting framework model. Elasticity is estimated in three stages of demand model. In the first stage of estimation of elasticity (E1), the response of demand towards food items with respect to changes in income was estimated. In E2 the response of change in demand in MFE with respect to changes in income was captured. In third stage of elasticity, the response of demand for fish with changes in income was estimated. Elasticity in stage 1 (E1), stage 2 (E2) and stage 3 (E3) was found to be 0.73, 1.15 and 1.02 respectively, as shown in table 2.

Over all Income elasticity (E) for all income groups is found to lies between 0 and 1 . This indicated that fish is a normal good for all income groups in Uttar Pradesh. Positive value (0 to 1$)$ of income elasticity of demand showed that the good is normal.

Table.1 Fish consumption in Uttar Pradesh

\begin{tabular}{|c|c|}
\hline Year & Consumption (kg/capita/ annum) \\
\hline 1983 & 1.34 \\
\hline 1987 & 0.78 \\
\hline 1993 & 0.78 \\
\hline 1999 & 1.14 \\
\hline 2004 & 1.10 \\
\hline 2011 & 1.10 \\
\hline
\end{tabular}


Table.2 Income elasticities

\begin{tabular}{|c|c|c|c|c|}
\hline Income Groups & E1 & E2 & E3 & E \\
\hline $\mathbf{1}$ & 0.73 & 1.15 & 1.02 & 0.85 \\
\hline $\mathbf{2}$ & 0.73 & 1.16 & 0.90 & 0.76 \\
\hline $\mathbf{3}$ & 0.73 & 1.16 & 0.80 & 0.68 \\
\hline $\mathbf{4}$ & 0.73 & 1.17 & 0.59 & 0.51 \\
\hline
\end{tabular}

Income group 1: Per capita weekly expenditure < Rs 85

Income group 2: Per capita weekly expenditure in the range Rs 85- 121

Income group 3: Per capita weekly expenditure in the range Rs 122 - 170

Income group 4: Per capita weekly expenditure $>$ Rs 170

Table.3 Price elasticity for fish among different income groups

\begin{tabular}{|c|c|c|}
\hline Income Groups & UP & CP \\
\hline 1 & -1.29 & -1.29 \\
\hline 2 & -1.32 & -1.32 \\
\hline 3 & -1.33 & -1.33 \\
\hline 4 & -1.37 & -1.37 \\
\hline
\end{tabular}

Fig.1 State of Uttar Pradesh, India (Source: Google Map 2016)

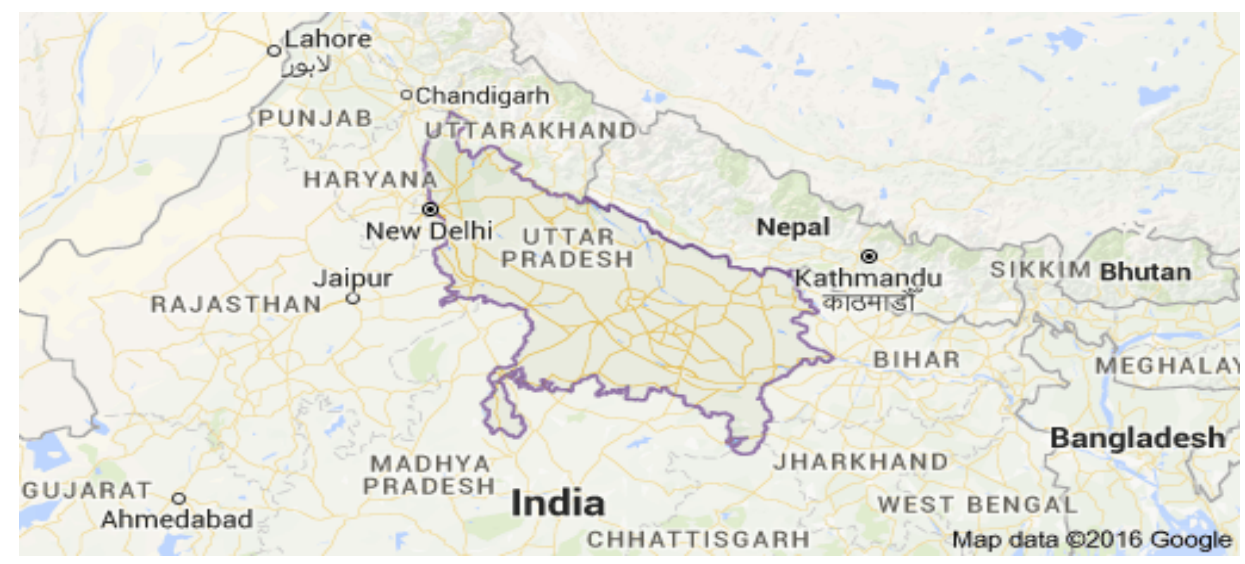

Fig.2 Pattern of Food and Non-food expenditure in Uttar Pradesh

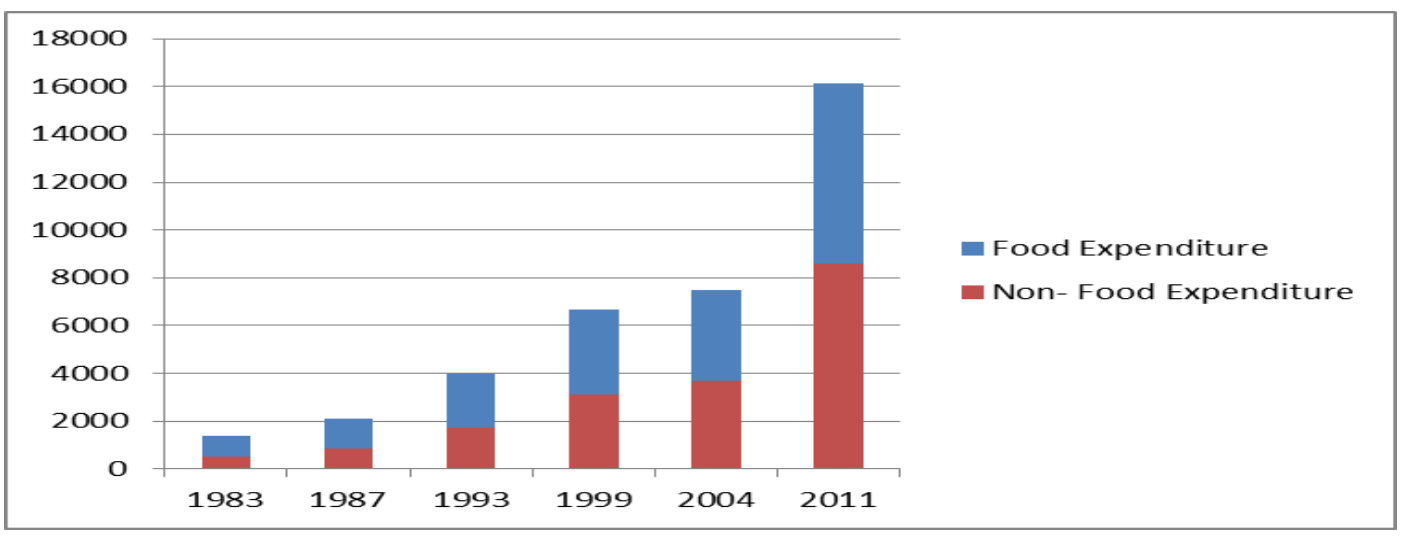


Fig.3 Share of fish in MFE

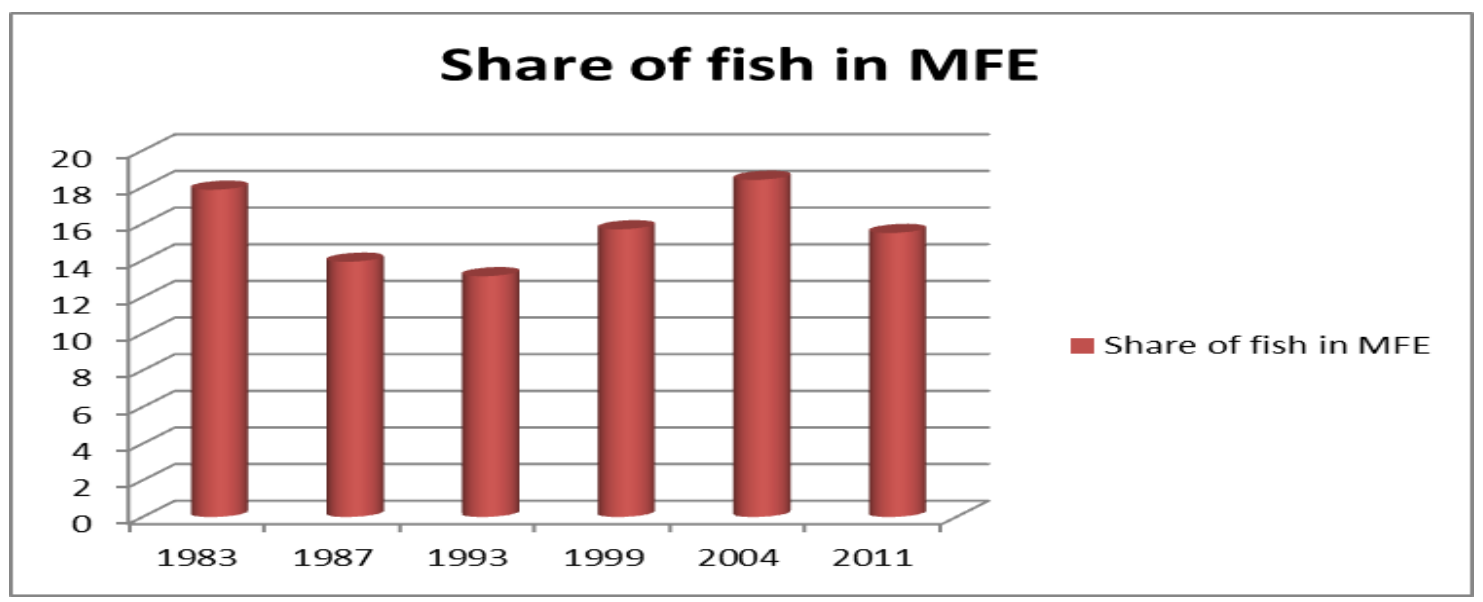

\section{Price Elasticity}

Change in demand with change in price is termed as price elasticities. There are two approaches to calculate price elasticity of demand which are Hicksian demand function and Marshallian demand function. Hicksian demand function gives compensated price elasticity (CP) of demand and Marshallian demand function gives uncompensated price elasticity (UP) of demand. The difference between the Hicksian demand function and Marshallian demand function is that in Hicksian system, the change in demand with change in price; leaves the consumer same utility level. Therefore it assumed that consumer gets compensated for the price increase through the increase in income. So, income effect is compensated and only substitution effect is left where as in Marshallian system income is constant while the utility level might change (Jacob Ramskov and Jesper Munksgaard, 2001).

Generally, price elasticity of demand is always negative. In case of Uttar Pradesh, overall price elasticity was found -1.32 , which indicated that demand for fish was elastic implying that the demand for fish in Uttar Pradesh was the function of price. Price elasticity for fish is not constant for each income group as shown in table 3 .
According to Slutsky compensated and uncompensated elasticities will be similar when the share of income devoted to the commodity low on the consumer demand schedule and therefore its income elasticity of that good is small. Here compensated and uncompensated price elasticity of demand for fish was found to be equal in Uttar Pradesh because of low share of expenditure on fish and low income elasticity.

Consumption of fish is very low in Uttar Pradesh because fish is an item that occupies a low place in the consumption schedule of the population since the states is dominated by vegetarians. Share of fish in MFE was low, which indicates that fish was not a preferred non-veg item among the population of Uttar Pradesh. Status of fish was found as a normal good in Uttar Pradesh because the income elasticity of demand was 0.77 , which is less than 1but more than 0.Demand for fish is elastic in Uttar Pradesh because price elasticity of demand for fish was found to be -1 .32.Increase in non-food expenditure was not very high with increase in income because of large number of poor in Uttar Pradesh. Generally non-food expenditure increased with increase in Income. The scope for increased fish consumption in Uttar Pradesh is directly proportionate to the size of the non-vegetarian population in the state. The probability of increased share of fish in consumption schedule of non-veg population 
of the state depends on the income, level of education, increased awareness of the contribution of fish in the nutritional profile, improved time, space and form utility of fish.

\section{References}

Asche, F., and Wessels, C.R. 1997. On price indices in the almost ideal demand system, American Journal of Agricultural Economics 79, 1182-1185.

Ayyappan, S., 2006. National aquaculture sector overview: India. National Aquaculture Sector Overview Fact Sheets. FAO, Rome. Available via FIGIS from: http://www. fao. org/figis/servlet/static.

Blundell, R., P. Pashardes and G. Weber, 1993. What do we learn about consumer demand patterns from micro data? American Economic Review, 83:570-597.

Deaton, A., and J. Muellbauer, 1980. An almost ideal demand system. American Economic Review, 70:312-326.

Dey, M.M., and M. Ahmed, 2005. Aquaculturefood and livelihoods for the poor in Asia: A brief overview of the issues. Aquaculture Economics \& Management, 9(1\&2):1-10.

Eales, J.S., and Unnevehr, L.J. 1988. Demand for beef and chicken products: separability and structural change, American Journal of Agricultural Economics 70, 521-532.

FAO. 2016. The State of World Fisheries and Aquaculture 2016. Contributing to food security and nutrition for all. Rome. $200 \mathrm{pp}$

Garcia, Y.T., M.M. Dey and S.M. Navarez, 2005. Demand for fish in the Philippines: A disaggregated analysis. Aquaculture Economics \& Management, 9(1\&2): 141165.

Heckman, J., 1979. Sample selection bias as a specification error, Econometrica 47, 153161.

Heien, D., and Wessells, C.R. 1990. Demand system estimation with microdata: a censored regression approach, Journal of Business and Economic Statistics 8, 365371.

Jacob Ramskov and Jesper Munksgaard, 2001. Elasticities - a Theoretical Introduction, 29.

Kumar Ravi Shankar, 2016. Estimation of demand for fish in Delhi and NCR, unpublished master of science (Fisheries Economics) dissertation, Fisheries Economics, Extension and Statics division, ICARCentral Institute of Fisheries Education, Mumbai 400061, India

Kumar, P., and M.M. Dey, 2004. A study on modelling of household demand for fish in India. Indian Journal of Agricultural Economics, 59(3): 465-475.

Lakra, 2010. Fish Biodiversity of Uttar Pradesh: Issues of livelihood security, Threats and conservation.

Moschini, G., 1995. Units of measurement and the stone index in demand system estimation, American Journal of Agricultural Economics 77, 63-68.

Mustapha, N., Ghaffar, R.A. and Poerwono, D. 1994. An almost ideal demand system analysis of fresh fish in Semarang, Indonesia, Journal of International Food and Agribusiness Marketing 6, 91-128.

Shonkwiler, J.S., and Yen, S. 1999. Two-step estimation of a censored system of equations, American Journal of Agricultural Economics 81, 972-982.

Tiffin, A., and R. Tiffin, 1999. Estimates of food demand elasticities for Great Britain: 19721994. Journal of Agricultural Economics, 50: 140-147.

Yen, S.T., and Roe, T. 1989. Estimation of a twolevel demand system with limited dependent variables, American Journal of Agricultural Economics 71, 85-99.

\section{How to cite this article:}

Ravi Shankar Kumar, Praduman Kumar, M. Krishnan, A. Vinay and Dhande Kranthi Kumar. 2017. Consumption Pattern of Fish in Uttar Pradesh, India. Int.J.Curr.Microbiol.App.Sci. 6(9): 2854-2861. doi: https://doi.org/10.20546/ijcmas.2017.609.350 